University of Pennsylvania Carey Law School

Penn Law: Legal Scholarship Repository

Faculty Scholarship at Penn Law

8-15-2019

\title{
Mashups and Fair Use: The Bold Misadventures of the Seussian Starship Enterprise
}

\author{
Peter Menell \\ Berkeley Law \\ Shyamkrishna Balganesh \\ University of Pennsylvania Carey Law School \\ David Nimmer \\ Irell \& Manella LLP
}

Follow this and additional works at: https://scholarship.law.upenn.edu/faculty_scholarship

Part of the Entertainment, Arts, and Sports Law Commons, Intellectual Property Law Commons, Jurisprudence Commons, Litigation Commons, and the Public Law and Legal Theory Commons

\section{Repository Citation}

Menell, Peter; Balganesh, Shyamkrishna; and Nimmer, David, "Mashups and Fair Use: The Bold Misadventures of the Seussian Starship Enterprise" (2019). Faculty Scholarship at Penn Law. 2220. https://scholarship.law.upenn.edu/faculty_scholarship/2220

This Article is brought to you for free and open access by Penn Law: Legal Scholarship Repository. It has been accepted for inclusion in Faculty Scholarship at Penn Law by an authorized administrator of Penn Law: Legal Scholarship Repository. For more information, please contact PennlawIR@law.upenn.edu. 


\title{
Mashups and Fair Use: The Bold Misadventures of the Seussian Starship Enterprise
}

\author{
Peter S. Menell, ${ }^{*}$ Shyamkrishna Balganesh, ${ }^{* *}$ and David Nimmer ${ }^{* * *}$
}

This amicus brief filed in the Ninth Circuit appeal of Dr. Seuss Enterprises v. ComicMix seeks to rectify and restore the balances underlying the Copyright Act of 1976_-particularly the interplay of the Section 106(2) right to prepare derivative works and the fair use doctrine. The District Court granted the defendants' motion for summary judgment on the ground that OH THE PlaCeS You'Ll BOLDLY Go! — the defendants' illustrated book combining Dr. Seuss's OH THE PlACES You'Ll Go! and other Dr. Seuss books with Star Trek characters and themes-made fair use of the Dr. Seuss works.

Based on the works at issue, uncontested facts, and the judge's factual findings, the amicus brief contends that defendants' unauthorized derivative work plainly supported a grant of summary judgment for the plaintiff on the fair use defense. The District Court's conclusory finding that the defendants' work is "highly transformative," disregard of the second and third fair use factors, analysis of the fourth factor, and allocation of the burden of proof misapply the standards for fair use analysis.

The District Court's decision destabilizes essential copyright law principles that have long supported markets for collaborations and derivative works. If this decision stands, competitors could flood publishing, television, film, and merchandising markets with unauthorized derivative works merely by "mashing” in other elements. Lucasfilm could produce OH THE Places YoDA'Ll Go! without obtaining a license from Dr. Seuss Enterprises. The developers of the Pokémon series could offer OH THE PlaCES You’LL Pokémon Go!. Castle Rock Entertainment could introduce OH THE PlACES You’Ll Yada Yada Yada!. Warner Bros. could freely mash together Bugs Bunny with Marvel Comic’s Iron Man or Sesame Street's Kermit the Frog. Moreover, anyone could produce and distribute such works. That result contravenes what Congress intended in establishing an exclusive right to prepare derivative works subject to the fair use defense.

While mashups can qualify for fair use in particular cases-for example, where they offer parodic or even satirical commentary and insights; or where a fan adapts his or her favorite characters or scenes for a school project-a categorical rule that commercial, non-parodic, nonsatirical mashups automatically qualify as "highly transformative" for purposes of fair use analysis goes well beyond the Copyright Act’s regime for promoting expressive creativity.

Promoting mashup art beyond the limits set by copyright law’s exclusive rights, limiting doctrines, and fair use analysis may well be a desirable policy reform for the digital age. Such a course, however, is for Congress and not the judiciary.

* Koret Professor of Law and Director, Berkeley Center for Law \& Technology, University of California at Berkeley School of Law

\footnotetext{
*** Professor of Law, Penn Law

*** Adjunct Faculty, UCLA Law
} 
No. $19-55348$

\section{------------------------------- ----------------------------- \\ IN THE UNITED STATES COURT OF APPEALS FOR THE NINTH CIRCUIT}

DR. SEUSS ENTERPRISES, L.P., a California limited partnership PLAINTIFF-APPELLANT,

V.

COMICMIX LLC, a Connecticut limited liability company; GLENN HAUMAN, an individual; DAVID JERROLD FRIEDMAN a/k/a DAVID GERROLD, and individual; and TY TEMPLETON, an individual, DEFENDANTS-APPELLEES.

On Appeal from the United States District Court
for the Southern District of California
16-CV-2779 JLS (BGS)
Bonorable Janet L. Sammartino, District Court Judge
BROFESSORS PETER S. MENELL, SHYAMKRISHNA BALGANESH
AND DAVID NIMMER IN SUPPORT OF PETITIONERS
PETER S. MENELL
Counsel of Record
Koret Professor of Law and Director
Berkeley Center for Law \& Technology
UC BERKELEY SCHOOL OF LAW
225 Bancroft Way
Berkeley, CA 94720
(510) 642-5489

August 12, 2019 


\section{CORPORATE DISCLOSURE STATEMENT}

Pursuant to Federal Rule of Appellate Procedure 26.1, the undersigned states that none of the amici are a corporation.

Dated: August 12, 2019

By: /s/ Peter S. Menell

Counsel for Amici Curiae 
This brief is submitted pursuant to Rule 29(a) of the Federal Rules of Appellate Procedure with the consent of the parties. No party’s counsel authored the brief in whole or in part; no party or party's counsel contributed money that was intended to fund preparing or submitting the brief; and no person other than the amici curiae or their counsel, contributed money that was intended to fund preparing or submitting the brief. Petitioners and Respondents have consented to the filing of this brief through blanket consent letters filed with the Clerk's Office.

Dated: August 12, 2019

By: /s/ Peter S. Menell

Counsel for Amici Curiae 


\section{TABLE OF CONTENTS}

CORPORATE DISCLOSURE STATEMENT …........................................... ii

STATEMENT OF COMPLIANCE WITH RULE 29 .................................... iii

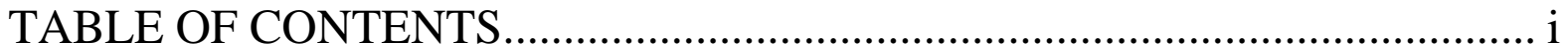

TABLE OF AUTHORITIES ......................................................................... iii

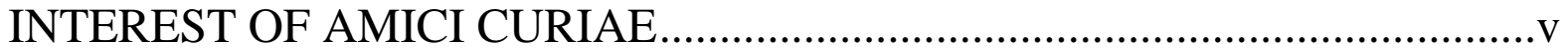

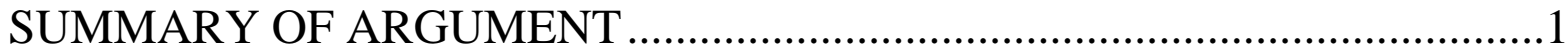

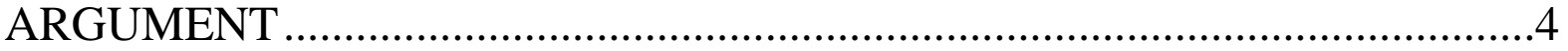

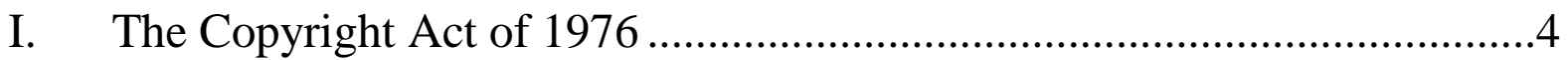

A. Section 106(2): The Right to Prepare Derivative Works............................5

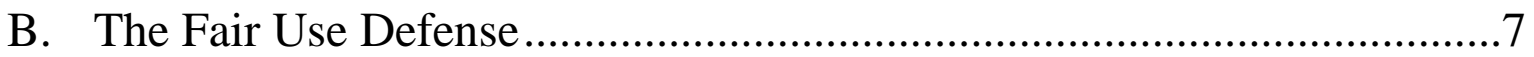

C. Reconciling Section 106(2) and Fair Use Jurisprudence.........................10

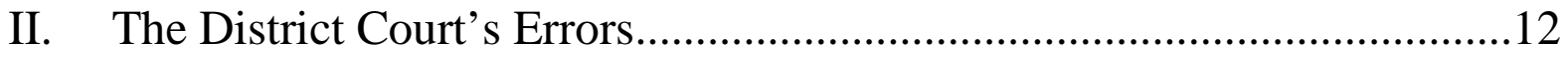

A. Evaluation of Transformativeness.........................................................12

B. Consideration of the Fair Use Factors....................................................14

1. Factor 1 (Purpose and Character of Use)...........................................14

2. Factor 2 (Nature of Copyrighted Work) ............................................14

3. Factor 3 (Amount and Substantiality of Copying)..............................15 
4. Factor 4 (Effect on Potential Market for Copyrighted Work) ..............17

5. Balancing the Fair Use Factors …..................................................20

III. Licensing, Institutional, Remedial, and Policy Considerations .................21

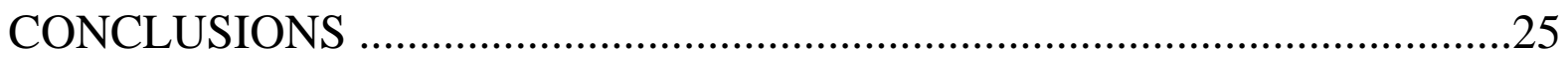




\section{TABLE OF AUTHORITIES}

\section{Cases}

Anderson v. Stallone, 11 U.S.P.Q.2d 1161 (C.D. Cal. 1989) ...................... 7, 19, 21

Bill Graham Archives v. Dorling Kindersley Ltd., 448 F.3d 605 (2d Cir. 2006)....23

Campbell v. Acuff-Rose Music, Inc., 510 U.S. 569 (1994)............................. passim

DSE v. ComicMix, 372 F.Supp.3d 1101(S.D. Cal. 2019)............................... passim

eBay, Inc. v. MercExchange, L.L.C., 547 U.S. 388 (2006) ........................... 22, 23

Equals Three, LLC v. Jukin Media, Inc., 139 F.Supp.3d 1094 (C.D. Cal. 2015).........

Folsom v. Marsh, 9 F. Cas. 342, 344 (1841) ........................................... 7, 8, 18

Harper \& Row v. Nation Enterprises, 471 U.S. 539 (1985) ..................................18

Kienitz v. Sconnie Nation LLC, 766 F.3d 756, 758-59 (7th Cir. 2014) ...................20

Leibovitz v. Paramount Pictures Corp., 137 F.3d 109 (2d Cir. 1998) ............. 14, 15

New Era Publications Int'l v. Henry Holt \& Co., 884 F.2d 659 (2d Cir. 1989)......23

Perfect 10, Inc. v. Amazon.com, Inc., 508 F.3d 1146 (9th Cir. 2007).....................19

Stowe v. Thomas, 23 F. Cas. 201, 208 (C.C.E.D. Pa. 1853) (No. 13,514) ................6

Suntrust v. Houghton Mifflin Co., 252 F.3d 1165 (11th Cir. 2001) ........................19

\section{Statutes}

17 U.S.C. § 101 $5,6,10$

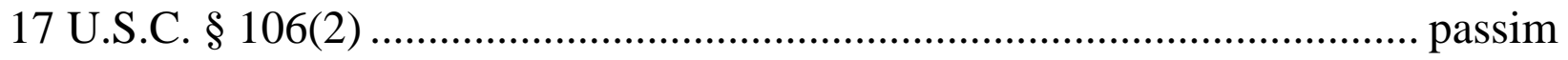




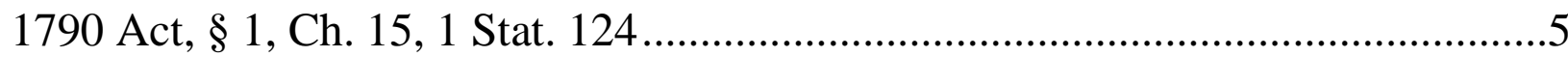

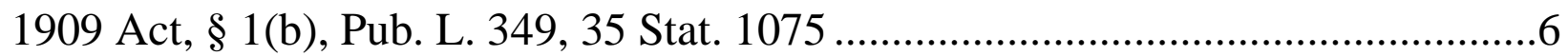

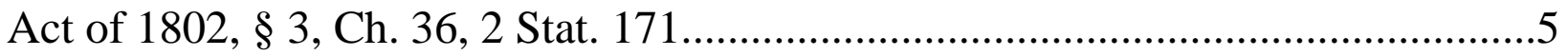

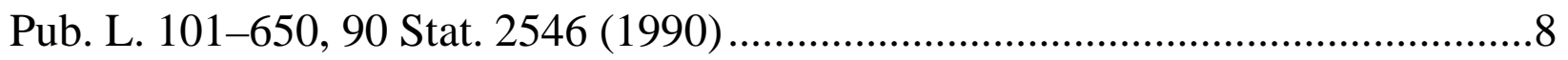

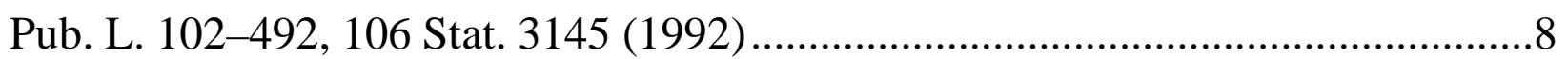

\section{Other Authorities}

Pierre Leval, Campbell As Fair Use Blueprint, 90 WASH. L. REV. 597 (2015)......11

Pierre Leval, Fair Use: A Ramble through the Bramble, NYU Proving IP Symposium, May 16, 2019, video available at

https://www.youtube.com/watch?v=OGky_yG8dV8

Pierre N. Leval, Toward a Fair Use Standard, 103 HARV. L. REV. 1105 (1990)

.passim

Peter S. Menell, Adapting Copyright for the Mashup Generation, 164 U. PA. L. REV. 441 (2016)....

Peter S. Menell \& Ben Depoorter, Using Fee Shifting to Promote Fair Use and Fair Licensing, 102 CAL. L. REV. 53 (2014)............................................. 23, 24

Jon O. Newman, Not the End of History: The Second Circuit Struggles with Fair Use, 37 J. COPYRIGHT SOC’y U.S.A. 12, 16 (1990) ............................................24

NIMMER ON COPYRIGHT § 13.05[A] [4], p. 13-102.61 ...........................................18

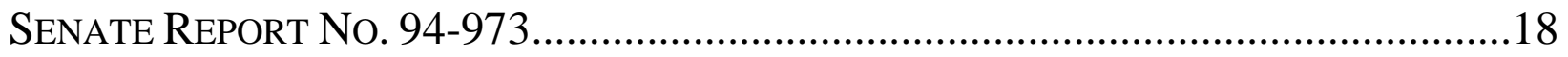




\section{INTEREST OF AMICI CURIAE}

The authors of this brief are law professors at the University of California and the University of Pennsylvania who study and teach intellectual property law.

Peter S. Menell holds a law degree and a doctorate degree in economics. He has focused much of his research and teaching on intellectual property law. Soon after joining the University of California at Berkeley School of Law faculty in 1990, he laid the groundwork to establish the Berkeley Center for Law \& Technology (BCLT), which he co-founded in 1995. Professor Menell has authored or co-authored more than 100 articles and 15 books, including leading casebooks on intellectual property. He has organized more than 60 intellectual property education programs for the Federal Judicial Center, including an annual multi-day program on "Intellectual Property in the Digital Age” since 1998. He has advised the U.S. Congress, federal agencies, and state Attorneys General on a wide range of intellectual property and antitrust matters. He served as Vice-Chair of the National Academies of Sciences project on copyright and innovation. He presented the Copyright Society of the U.S.A.'s $42^{\text {nd }}$ Annual Donald C. Brace Memorial Lecture in 2011.

Shyamkrishna Balganesh is a Professor of Law at the University of Pennsylvania and researches and writes on copyright law and its connection to the common law. He has written extensively on the role of courts and judges in the 
intellectual property system, and his most recent work explores the interaction between statutory law and judge-made law in the evolution of U.S. copyright law. His published work has appeared in the HARVARD LAW REVIEW, YALE LAW Journal, StANFord LAW REVIEW, Columbia LAW REVIEW, and CALIFORNIA LAW REVIEW among other journals.

David Nimmer teaches copyright and other subjects at the UCLA School of Law. Since 1985, he has authored NIMMER ON COPYRIGHT, the standard treatise on the subject which his father launched in 1963. Besides publishing fifty articles, Professor Nimmer has lectured about U.S. and international copyright across the world. In 2019, he delivered the Manges Lecture at Columbia University and the 50th Year Commemoration for the Los Angeles Copyright Society. 
SUMMARY OF ARGUMENT

Copyright law’s fair use defense is one of the most vexing doctrines in all of the law. From its emergence nearly two centuries ago through the present, courts have struggled with and lamented its complexity, unpredictability, and subjectivity. The reporters are replete with cases that could have gone either way.

This case, however, does not fall into the gray area. Based on the works at issue, uncontested facts, and the judge's factual findings, the defendants' unauthorized derivative work plainly supported a grant of summary judgment for the plaintiff on the fair use defense. Defendants produced OH THE PlACES You'LL BoldLy Go! [“BoldLY”], a non-parodic mashup that combines Star Trek with Dr. Seuss’s OH the Places You’Ll Go! [“Go!”]. BoldLY’s slavish use of imaginative graphic images and text from Go! results in a commercial work that would, if marketed, directly compete with Go!'s graduation season book sales and licensing marketplaces. The result does not qualify for the fair use defense.

The district court's conclusory finding that the defendants' work is "highly transformative” and disregard of the second and third fair use factors misapply the standards for fair use analysis. More troublingly, the court's categorical determination that "mashups" are inherently "highly transformative” for purposes of fair use analysis improperly undermines the Copyright Act's right to prepare 
derivative works and the proper role for the fair use defense. Moreover, the district court's shifting of the burden of proof regarding market harm to the copyright owner contravenes basic tenets of civil procedure.

The District Court's decision destabilizes essential copyright law principles that have long supported markets for collaborations and derivative works. If this decision stands, competitors could flood publishing, television, film, and merchandising markets with unauthorized derivative works merely by “mashing” in other elements. Lucasfilm could produce OH THE PLACES YODA'LL Go! without obtaining a license from Dr. Seuss Enterprises [“DSE”]. The developers of the Pokémon series could offer OH THE Places You’Ll Pokémon Go!. Castle Rock Entertainment could introduce OH the Places You’Ll Yada Yada Yada!. Warner Bros. could freely mash together Bugs Bunny with Marvel Comic’s Iron Man or Sesame Street’s Kermit the Frog.

Moreover, anyone could produce and distribute such works. The defendants in this case did not license rights from the owners of the Star Trek series or DSE. That result contravenes what Congress intended in establishing an exclusive right to prepare derivative works subject to the fair use defense.

While mashups can qualify for fair use in particular cases_-for example, where they offer parodic or even satirical commentary and insights; or where a fan adapts his or her favorite characters or scenes for a school project—a categorical 
rule that commercial, non-parodic, non-satirical mashups automatically qualify as "highly transformative" for purposes of fair use analysis goes well beyond the Copyright Act's regime for promoting expressive creativity. Reversing the district court's decision, therefore, is critical to ensuring that the Copyright Act's exclusive rights, limiting principles, and policies, and the licensing institutions and norms they have generated, continue to function effectively. By contrast, affirming the district court’s decision would undermine Congress’s copyright protection framework and threaten chaos in the content industries.

None of this is to suggest that the fair use doctrine is not an important feature of copyright law or that individuals should not be able to express their creativity or engage with influential works. It is essential, however, that the courts not subvert the copyright system by holding that any mashup constitutes fair use. The District Court's decision is not merely a slippery slope undercutting the statutory right to prepare derivative works; it is a precipice.

Promoting mashup art beyond the limits set by copyright law’s exclusive rights, limiting doctrines, and fair use analysis may well be a desirable policy reform for the digital age. Such a course, however, is for Congress and not the judiciary. 


\begin{abstract}
ARGUMENT
As copyright scholars who seek to promote a balanced copyright system and fidelity to legislative authority, we file this brief to rectify and restore the balances underlying the Copyright Act of 1976. The factual background for this case is presented clearly in the District Court's rulings. After explaining the pertinent statutory provisions (17 U.S.C. $\S \S 106(2), 107)$ and their interplay, we focus on three principal errors made by the court below: (1) the conclusory determination that BOLDLY is "highly transformative"; (2) flawed analysis of the fair use factors; and (3) inappropriate shifting of the burden of proof of an affirmative defense on to the copyright owner. The final section explores the larger licensing, institutional, remedial, and policy aspects of this case.
\end{abstract}

\title{
I. The Copyright Act of 1976
}

Since the nation's founding, Congress and the courts have striven to promote expressive creativity through the development of a robust and balanced copyright system. This case involves the interplay of the § 106(2) right to prepare derivative works and the § 107 fair use defense.

The District Court's hasty rejection of the relevance of the $\S 106(2)$ right—by blithely noting that copyright's exclusive rights are subject to the fair use defense, see DSE v. ComicMix, 372 F.Supp.3d 1101, 1116 (S.D. Cal. 2019)—overlooks 
important statutory context for understanding "transformativeness.” Congress defines “derivative works" as works that "recast, transform[], or adapt[]" "preexisting works.” 17 U.S.C. § 101 (emphasis added). If, as the District Court ruled, non-parodic, non-critical, conventional mashups are inherently "highly transformative” under $\S 107$ and such finding resolves all of the factors in the defendant's favor, then the right to prepare derivative works has no purchase for any adaptation that combines pre-existing works. Congress did not intend such a broad exemption. The resolution of this puzzle—and the dual meaning of “transform”- - lies in a deeper understanding of Sections 106(2) and 107.

\section{A. Section 106(2): The Right to Prepare Derivative Works}

Pursuant to Art. I, Section 8, Clause 8 of the U.S. Constitution, Congress granted authors exclusive rights to books and other creative works for limited times. The 1790 Act granted authors of books, maps, and charts exclusive timelimited rights. See 1790 Act, § 1, Ch. 15, 1 Stat. 124. A dozen years later Congress recognized derivative work protection by extending copyright protection to prints. See Act of 1802, § 3, Ch. 36, 2 Stat. 171 (imposing liability upon those “copy or sell, or cause to be engraved, etched, copied or sold, in the whole or in part, by varying, adding to, or diminishing from the main design, or shall print, reprint, or import for sale, or cause to be printed, re-printed, or imported for sale, any such print or prints, or any parts thereof, without the consent of the proprietor or 
proprietors thereof” (emphasis added).

The extent of adaptation rights remained murky during the $19^{\text {th }}$ century, with some cases declining to find translations and creative abridgements to implicate the right to copy. See, e.g., Stowe v. Thomas, 23 F. Cas. 201, 208 (C.C.E.D. Pa. 1853) (No. 13,514) (concerning German translation of Uncle Tom's Cabin). Congress removed any doubt in the 1909 Act, granting authors the exclusive right to "translate the copyrighted work into other languages or dialects or make any other version thereof if it be a literary work; to dramatize it if it be a nondramatic work; to convert it into a novel or other nondramatic work if it be a drama; to arrange or adapt it if it be a musical work; to complete, execute, and finish it if it be a model or design for a work of art.” See 1909 Act, § 1(b), Pub. L. 349, 35 Stat. 1075.

Congress explicated the derivative work right in the Copyright Act of 1976. Section 106(2) grants authors the exclusive right "to prepare derivative works based on the copyrighted work." The Act defines a "derivative work" as "a work based upon one or more preexisting works, such as a translation, musical arrangement, dramatization, fictionalization, motion picture version, sound recording, art reproduction, abridgment, condensation, or any other form in which a work may be recast, transformed, or adapted. ...” 17 U.S.C. § 101 (emphasis added).

Thus, a work that transforms a pre-existing work falls within the exclusive 
rights of the owner of copyright in the pre-existing work. Section 103(a) provides that "protection for a work employing preexisting material in which copyright subsists does not extend to any part of the work in which such material has been used unlawfully.” See generally Anderson v. Stallone, 11 U.S.P.Q.2d 1161 (C.D. Cal. 1989) (finding that a script about Rocky Balboa fighting a Russian boxer infringes the right to prepare derivative works). All of the $\S 106$ rights are subject to the $\S 107$ defense.

\section{B. The Fair Use Defense}

Early court decisions recognized that "the question of piracy" often depends upon a balance of factors, giving rise to the fair use doctrine. Folsom v. Marsh, 9 F. Cas. 342, 344 (1841) (Story, J.). Courts evolved the fair use doctrine through hundreds of published opinions over more than a century, ultimately leading Congress to codify the fair use defense in the 1976 Act:

Notwithstanding the provisions of sections 106, the fair use of a copyrighted work, including such use by reproduction in copies or phonorecords or by any other means specified by that section, for purposes such as criticism, comment, news reporting, teaching (including multiple copies for classroom use), scholarship, or research, is not an infringement of copyright. In determining whether the use made of a work in any particular case is a fair use the factors to be considered shall include-

(1) the purpose and character of the use, including whether such use is of a commercial nature or is for nonprofit educational purposes;

(2) the nature of the copyrighted work;

(3) the amount and substantiality of the portion used in relation to the copyrighted work as a whole; and 
(4) the effect of the use upon the potential market for or value of the copyrighted work.

17 U.S.C. $\S 107 .{ }^{1}$ In codifying this jurisprudence, Congress recognized the judiciary’s ongoing role in developing the fair use doctrine. See Copyright Law

Revision, H.R. Rep. No. 94-1476, at 66 (1976).

Drawing on Justice Story's inquiry whether a new work merely "supersedes the objects" of the original creation or instead adds something new, Folsom v. Marsh, 9 F. Cas. at 348, Judge Pierre Leval introduced the term "transformativeness" to elucidate fair use analysis:

I believe the answer to the question of justification turns primarily on whether, and to what extent, the challenged use is transformative. The use must be productive and must employ the quoted matter in a different manner or for a different purpose from the original. ... [If] the secondary use adds value to the original - if the quoted matter is used as raw material, transformed in the creation of new information, new aesthetics, new insights and understandings - this is the very type of activity that the fair use doctrine intends to protect for the enrichment of society.

Pierre N. Leval, Toward a Fair Use Standard, 103 HARV. L. REV. 1105, 1111 (1990) (footnotes omitted, emphases added). He did not, however, view "[t]he existence of

${ }^{1}$ Congress later applied fair use to newly enacted moral rights provision in $\S$ 106A, Pub. L. 101-650, 90 Stat. 2546, § 607 (1990), and added the following in 1992: "The fact that a work is unpublished shall not itself bar a finding of fair use if such finding is made upon consideration of all the above factors," Pub. L. 102492, Oct. 24, 1992, 106 Stat. 3145. 
any identifiable transformative objective” as the end of the inquiry. Id. at 1111.

Judge Leval explained:

Courts must consider the question of fair use for each challenged passage and not merely for the secondary work overall. ... Simply to appraise the overall character of the challenged work tells little about whether the various quotations of the original author's writings have a fair use purpose or merely supersede. For example, in the recent cases of biographies of Igor Stravinsky and J.D. Salinger, although each biography overall served a useful, educational, and instructive purpose that tended to favor the defendant, some quotations from the writings of Stravinsky and Salinger were not justified by a strong transformative secondary objective. The biographers took dazzling passages of the original writing because they made good reading, not because such quotation was vital to demonstrate an objective of the biographers. These were takings of protected expression without sufficient transformative justification.

Leval, 103 HARV. L. REV. at 1111-12 (footnotes omitted).

Drawing on Justice Story’s formulation, Judge Leval’s insights and terminology, and Congress's preambular examples, the Supreme Court reversed the Sixth Circuit's ruling denying the fair use defense to 2 Live Crew's parodic version of “Oh, Pretty Woman.” See Campbell v. Acuff-Rose Music, Inc., 510 U.S. 569 (1994). The Court's decision did not, however, hold that a finding that a work is transformative runs the table of fair use factors. To the contrary, the Court noted that even works with parodic elements could adversely affect the copyright owner's legitimate potential markets and such effects must be carefully analyzed. See id. at 593-94. 


\section{Reconciling Section 106(2) and Fair Use Jurisprudence}

As noted above, use of the term "transformative" in fair use jurisprudence emerged long after passage of the 1976 Act. Neither Judge Leval nor Justice Souter in Campbell expressly discussed the terminological overlap between $\S 101$ (definition of "derivative work") and fair use jurisprudence, but it is clear that they did not intend for fair use to swallow a large portion of the right to prepare derivative works. Absent constitutional violations, the judiciary cannot override Congress's express statutory framework. Thus, this terminology must be understood against the backdrop of the Copyright Act. Judge Leval recognized that:

The transformative justification must overcome factors favoring the copyright owner. A biographer or critic of a writer may contend that unlimited quotation enriches the portrait or justifies the criticism. The creator of a derivative work based on the original creation of another may claim absolute entitlement because of the transformation. Nonetheless, extensive takings may impinge on creative incentives. And the secondary user's claim under the first factor is weakened to the extent that her takings exceed the asserted justification. The justification will likely be outweighed if the takings are excessive and other factors favor the copyright owner.

Leval, 103 HARV. L. REV. at 1111.

In discussing the fourth factor (effect on the potential market), often labeled the most important consideration, Justice Souter recognized that although " $[t]$ he market for potential derivative uses includes only those that creators of original works would in general develop or license others to develop," which likely excludes critical reviews or lampoons, works that comprise parody and other elements could 
nonetheless harm legitimate derivative licensing markets such as the general market for rap music. See Campbell, 510 U.S. at 592. "Evidence of substantial harm to [such market] would weigh against a finding of fair use, because the licensing of derivatives is an important economic incentive to the creation of originals. See 17 U.S.C. § 106(2) (copyright owner has rights to derivative works).” Campbell, 510 U.S. at 593. In that manner, the Supreme Court's fair use analysis recognized the continuing need to respect the copyright owner's rights in derivatives.

Judge Leval has more recently clarified the meaning of transformative as applied to $\S 106(2)$ and fair use analysis:

Transformations of the sort producing fair use are usually of a different character from the transformations that produce derivatives. In the fair use context, the word most frequently refers to the purpose of the copyingordinarily to communicate some kind of commentary about the original or provide information about it. ...

In the derivative context, by contrast, what Campbell refers to as the 'critical bearing' of the secondary work will generally be absent. The transformation involved in making a derivative is usually one of form or medium, offering the same work in a new version, form, medium, or shape, rather than offering information or commentary about the original.

The classic understanding of derivatives is that they are works that represent the original author's creative expression in a different medium or form to an audience that either is, or would be, motivated by appreciation of the original author's creative expression. ...

See Pierre Leval, Campbell As Fair Use Blueprint, 90 WASH. L. REv. 597, 609-10 (2015) (footnote omitted). A few months ago, Judge Leval embroidered on those considerations to explain that 
a common form of copying that is neither parodic nor satirical, where one simply piggybacks on a famous song, poem or passage, or logo, playing on public recognition of the original to give punch, or humor to a new, unrelated message. Where the copying is essentially either to harness the expressive brilliance of the original for the delivery of the copier's message, or to gain audience impact for the new message by free-riding on the fame of the original expression, courts should ponder whether such changes can qualify as transformative, whether they have arguable justification for copying. It is difficult to see why the original author should not be entitled to a fee for licensing such a utilization of her work.

Pierre Leval, Fair Use: A Ramble through the Bramble, NYU Proving IP Symposium, May 16, 2019, video available at https://www.youtube.com/watch?v=OGky_yG8dV8 (at 11:48 - 12:46).

\section{The District Court's Errors}

BOLDLY is less deserving of fair use than a work condemned by Judge Leval which "simply piggybacks on a famous [work] playing on public recognition of the original to give punch, or humor to a new, unrelated message.” Id. Here the defendants did not even provide a "new, unrelated message.” Yet the District Court collapsed the assessment of fair use by ruling that combining Star Trek characters, settings, and themes with the vivid imagery and prose of Dr. Seuss's Go! (and other works) was "highly transformative.” This produced a domino effect by which a conclusory judgment on transformativeness toppled the fair use factors.

\section{A. Evaluation of Transformativeness}

While BOLDLY might well strike a lay observer as clever, engaging, and even 
transformative in a common parlance sense of the term, copyright's fair use test demands more than a simplistic test. As set forth in Part I, the inquiry focuses on whether the defendant's work serves a different privileged purpose than the original work. The $\S 107$ preamble identifies “criticism, comment, news reporting, teaching[], scholarship, or research” as prototypical fair use purposes, none of which remotely characterize BOLDLY. The District Court properly rejects the defendants’ assertion that BOLDLY parodies Go!, but nonetheless concludes that BOLDLY is transformative based on its allegedly different intrinsic purpose. According to the District Court, whereas Go! functions as an illustrated book with an uplifting message that would appeal to graduating high school and college seniors, BOLDLY offers an uplifting message in an illustrated book (drawing on Go!'s prose and imagery) “tailored to fans of Star Trek’s Original Series.” See DSE v. ComicMix, 372 F.Supp.3d at 1115. The District Court then sidesteps the more appropriate characterization: BoLDLY is a Go! sequel. See id. at 1116.

As the District Court correctly notes, derivative works can qualify for fair use. But without a different privileged purpose such as a criticism or commentary, they face a steep uphill climb. Even parodies have to survive the justificatory gantlet. See Campbell, 510 U.S. at 580 (observing that if the defendant's work "has no critical bearing on the substance or style of the original composition, which the alleged infringer merely uses to get attention or to avoid drudgery in working up 
something fresh, the claim to fairness in borrowing from another's work

diminishes accordingly (if it does not vanish), and other factors, like the extent of its commerciality, looms larger”).

\section{B. Consideration of the Fair Use Factors}

\section{Factor 1 (Purpose and Character of Use)}

Section 107(1) asks courts to consider "the purpose and character of the use, including whether such use is of a commercial nature or is for nonprofit educational purposes.” Fair use jurisprudence emphasizes whether the defendant's work merely supersedes the objects of the original or "is productive and employ[s] the quoted matter in a different manner or for a different purpose from the original.” See Leval, 103 HARV. L. REV. at 1111 (footnote omitted).

BOLDLY is an unabashedly commercial work that seeks to draw on Go!'s popularity. It entertains and inspires its target audience in much the way as Go! It parallels Go!'s creative style, imagery, and general purpose. By combining Star Trek characters, themes, and space travel with Go!, BoLDLY only modestly adds new insight and understanding. Dr. Seuss's imaginative imagery already reflects alien/extra-terrestrial settings and characters. This factor favors the plaintiff.

\section{Factor 2 (Nature of Copyrighted Work)}

Go! is an imaginative, expressive, highly original work of graphic art and prose. This factor favors the plaintiff. 


\section{Factor 3 (Amount and Substantiality of Copying)}

Drawing a questionable analogy to Leibovitz v. Paramount Pictures Corp., 137 F.3d 109 (2d Cir. 1998), a case distinguishable by the thinness of the copyright there at issue, the District Court focuses its factor 3 analysis on one comparison: the covers of the two works. See DSE v. ComicMix, 372 F.Supp.3d at 1118 . The only image at issue in Leibovitz was the magazine cover. The District Court properly determined that the BOLDLY cover copies little from Go!'s cover. We would go further and assert that BOLDLY's cover likely does not even infringe Go!'s cover.
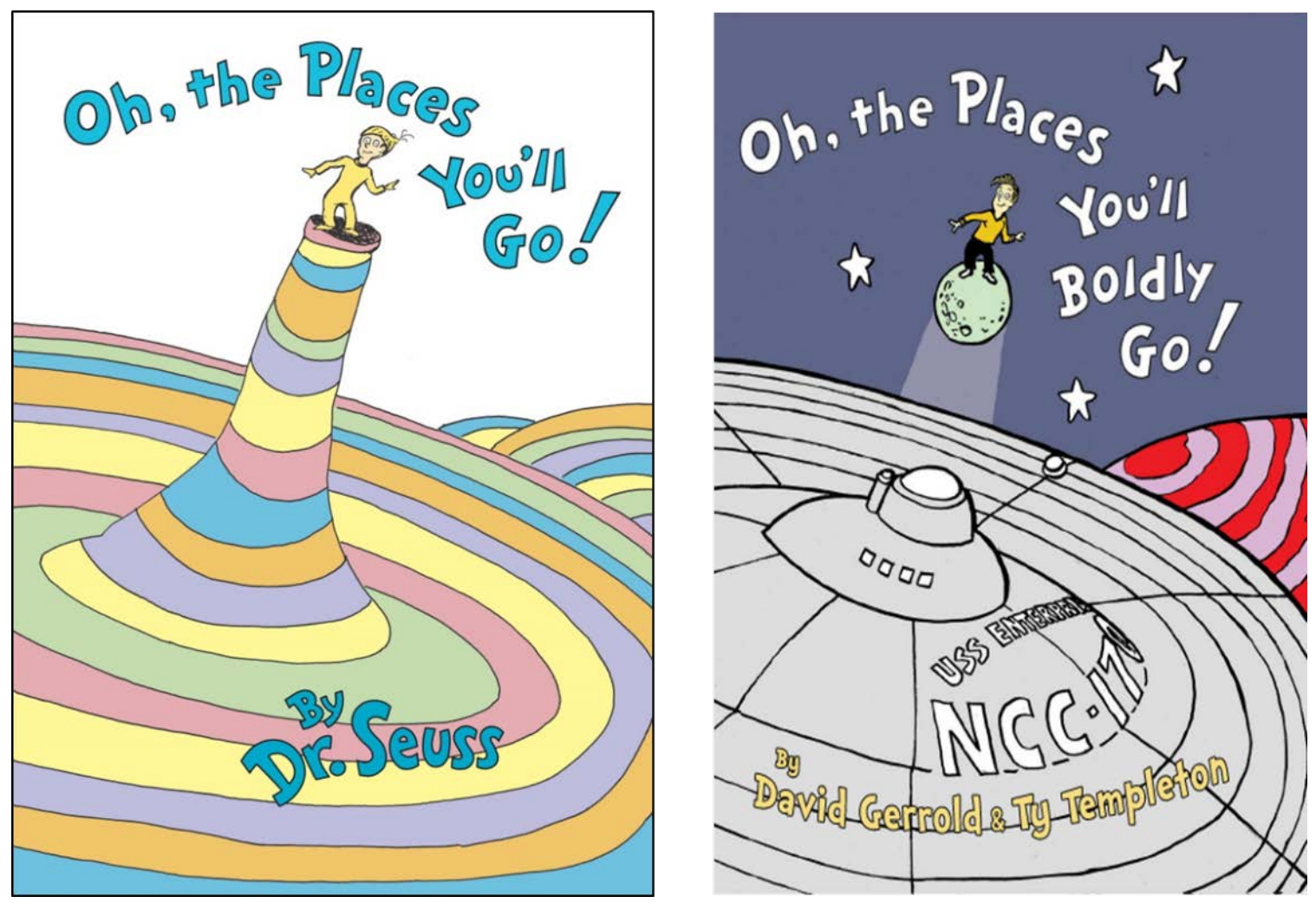

These observations, however, are entirely beside the point—one must not judge

a book by its cover. Insofar as the covers in this case are legally significant, they 
relate to the plaintiff's trademark cause of action, not the copyright cause of action. More importantly, as Judge Leval notes, “[c]ourts must consider the question of fair use for each challenged passage [or image] and not merely for the secondary work overall [or its cover].” Leval, 103 HARV. L. REV. at 1111 (our bracketed text). The following illustrations, not even analyzed by the District Court, demonstrate that BoLDLY (on the right) slavishly copied highly original illustrations from Go! and other Dr. Seuss works (on the left):
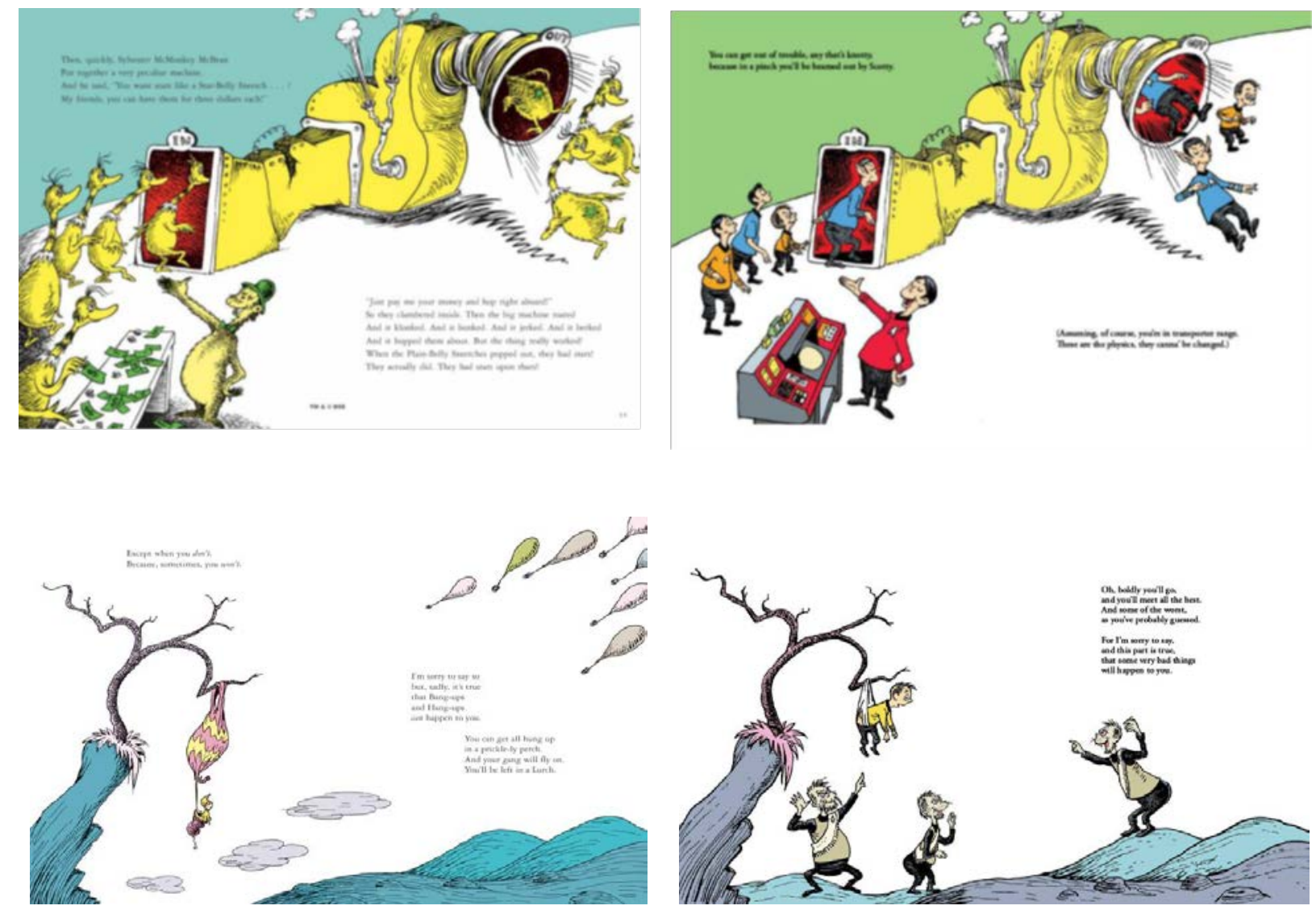

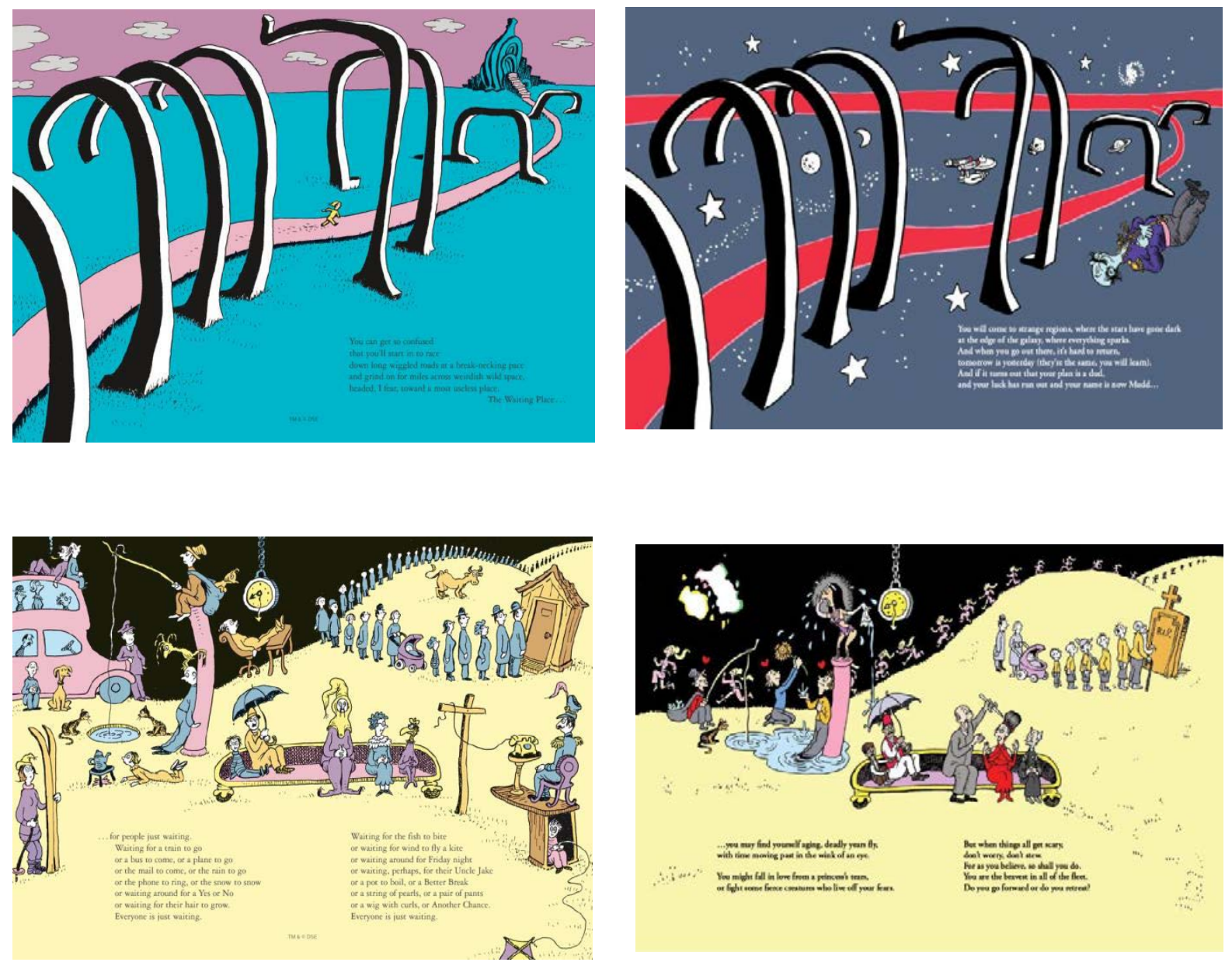

BOLDLY essentially traces highly imaginative graphic images, color patterns, and compilations of artistic elements. Such extensive copying cannot be justified by parodic, critical, or other privileged justification. The third factor favors the plaintiff.

\section{Factor 4 (Effect on Potential Market for Copyrighted Work)}

The fourth fair use factor examines the effect of the defendant's work on the potential market(s) for the plaintiff's work. This factor

requires courts to consider not only the extent of market harm caused by the particular actions of the alleged infringer, but also "whether unrestricted and widespread conduct of the sort engaged in by the defendant ... would result in a substantially adverse impact on the potential market” for the original. 
NIMMER § 13.05[A] [4], p. 13-102.61 (footnote omitted); accord, Harper \& Row, 471 U.S., at 569, at 2235; Senate Report, p. 65; Folsom v. Marsh, 9 F.Cas., at 349. The enquiry "must take account not only of harm to the original but also of harm to the market for derivative works." Harper \& Row, supra, 471 U.S. at 568.

Campbell, 510 U.S. at 590.

In many fair use cases, determining the potential market(s) for the plaintiff's work can be difficult. This is not such a case. Go! is a perennial bestseller during high school and college graduation season. In addition, there is a robust market for licensing Dr. Seuss works for collaborative books, audiovisual works, clothing, and merchandise. The defendants and their business partners recognized that BOLDLY would be a big hit during graduation season and could be exploited with posters, mugs, and other merchandise.

Nonetheless, the District Court concluded that "Plaintiff has failed to sustain its burden to demonstrate by a preponderance of the evidence that BOLDLY is likely substantially to harm the market for Go! or licensed derivatives of Go!.” DSE $v$. ComicMix, 372 F.Supp.3d at 1120. Even putting aside the District Court's error in imposing the burden of proof for the fourth fair use factor on the plaintiff, ${ }^{2}$ the District Court's ruling makes no sense. 
Brick and mortar bookstores would undoubtedly stock BOLDLY in close proximity to Go! during graduation season. Online search engines would quickly recommend these books to graduation gift shoppers. It is not difficult to imagine that searches for Go! would return recommendations for BOLDLY. Customers interested in an entertaining aspirational book for their grandchild, nephew, or niece would undoubtedly consider these books substitutes and choose the most appropriate-perhaps Go! for the humanities or law graduate and BOLDLY for the STEM (Science, Technology, Engineering, and Math) graduate. Unlike works that target audiences outside the original work's market—such as 2 Live Crew's parodic rap version of “Oh, Pretty Woman” or Alice Randall’s wrenching retelling of Gone with the Wind from the standpoint of slaves on the Tara plantation, see Suntrust $v$. Houghton Mifflin Co., 252 F.3d 1165 (11th Cir. 2001)—BoLDLY would supplant Go! sales.

Plaintiff also demonstrated that Go! and other Dr. Seuss works enjoy a robust licensing market. The District Court's decision serves as open invitation for anyone to enter the market for Dr. Seuss mashups. BOLDLY usurps the opportunity for DSE and the owners of the Star Trek series from pursuing collaboration. Cf. Anderson $v$. Stallone, 11 U.S.P.Q.2d 1161 (C.D. Cal. 1989).

The District Court's comparisons to Perfect 10, Inc. v. Amazon.com, Inc., 508 F.3d 1146 (9th Cir. 2007), and Equals Three, LLC v. Jukin Media, Inc., 139 
F.Supp.3d 1094 (C.D. Cal. 2015), bear little relevance to the present case. Google’s use of thumbnails of copyrighted images for purposes of its image search engine is transformative in a functional manner that bears no relationship to the present case. More directly, low resolution thumbnails do not compete with Perfect 10's high resolution images. To the contrary, Google's image search engine might well drive demand for Perfect 10's photographs. Equals Three involved speculative potential markets unlike those at issue here.

The fourth factor favors the plaintiff.

\section{Balancing the Fair Use Factors}

Contrary to the District Court's grant of summary judgment for the defendants, the fair use factors favor the plaintiff. BOLDY neither ridicules nor comments on Go! nor uses Go! to poke fun at Star Trek. BoLDLY pays homage to both as it seeks to commercialize a derivative work. While marketing a Star Trek themed version of Go! for STEM graduates appears to be a promising marketing idea, it nonetheless falls within plaintiff's right to prepare derivative works. If merely combining Go! with another work—-such as Star Wars, Pokémon, and Seinfeld —qualified as a transformative fair use, little would remain of the $\S 106(2)$ right. Fidelity to the Copyright Act requires that courts apply the fair use doctrine with due regard for copyright law’s right to prepare derivative works. See Kienitz v. Sconnie Nation LLC, 766 F.3d 756, 758-59 (7th Cir. 2014). DSE has licensed authors and 
illustrators to publish several Go! derivative works. This case does not implicate fundamental First Amendment concerns that would arise with critical commentary. Hence, BOLDLY is better viewed as an unauthorized derivative work that falls outside of the fair use defense.

\section{Licensing, Institutional, Remedial, and Policy Considerations}

Notwithstanding the District Court's flawed application of the fair use doctrine, we would be disingenuous if we did not acknowledge our desire to experience the adventures of a Seussian Starship Enterprise. The BoLDLY images and storyline combine memorable, engaging, and inspiring childhood memories.

The Copyright Act offers multiple possibilities to launch that adventure. First, Section 106(2) places the entitlement to pursue such a work squarely within the authority of DSE and the owner of the Star Trek franchise. Those companies can offer their own mashup of Dr. Seuss and the Starship Enterprise. This would be analogous to Sylvester Stallone’s production of Rocky IV (arguably the best of the Rocky sequels). See Anderson v. Stallone, 11 U.S.P.Q.2d 1161 (C.D. Cal. 1989). ${ }^{3}$

Second, DSE and the Star Trek franchise could join forces with the defendants

${ }^{3}$ Stallone independently came up with the idea of Rocky fighting a Soviet boxing powerhouse. See Anderson, 11 U.S.P.Q.2d at 1161 (quoting Stallone interview in WACO Tribune Herald, May 28, 1982; Section D, pg. 1; Anderson did not prepare his treatment until June 1982). 
to pursue a collaboration. Much of the creative work has been done.

Unfortunately, the defendants may have poisoned the well by taking such a cavalier approach to the projects. Nonetheless, the possibility still remains for such a venture, subject perchance to an intergalactic peace treaty among the parties.

Third, in appropriate cases (albeit not this one), derivative works could reach the public through a non-injunctive remedy, such as a running royalty damages award. The Supreme Court's decision in eBay, Inc. v. MercExchange, L.L.C., 547

U.S. 388 (2006), provides that

a plaintiff seeking a permanent injunction must satisfy a four-factor test . . . (1) that it has suffered an irreparable injury; (2) that remedies available at law, such as monetary damages, are inadequate to compensate for that injury; (3) that, considering the balance of hardships between the plaintiff and defendant, a remedy in equity is warranted; and (4) that the public interest would not be disserved by a permanent injunction.”).

Id. at 391. Judge Leval laments in his seminal pre-eBay article that [o]ne of the most unfortunate tendencies in the law surrounding fair use is the notion that rejection of a fair use defense necessarily implicates the grant of an injunction. Many commentators have disparaged the overly automatic tendency of courts to grant injunctive relief. The copyright statute and its predecessors express no preference for injunctive relief. The 1976 Act states only that a court "may ... grant temporary and final injunctions on such terms as it may deem reasonable to prevent or restrain infringement of a copyright.” Moreover, the tendency toward the automatic injunction can harm the interests of plaintiff copyright owners, as well as the interests of the public and the secondary user. Courts may instinctively shy away from a justified finding of infringement if they perceive an unjustified injunction as the inevitable consequence. 
Leval, 103 HARV. L. REV. at 1130-31 (footnotes omitted); see id. at 1131-35; New Era Publications Int'l v. Henry Holt \& Co., 884 F.2d 659, 663 n. 1, 664 (2d Cir. 1989) (Newman, J., dissenting) (advocating rehearing en banc and emphasizing the importance of the public interest in determining the availability of an injunction).

Just as courts have fashioned a balanced framework for assessing fair use, the eBay decision affords courts an opportunity to develop a further safety valve that preserves incentives to create, balances compensation for authors, and promotes dissemination of cumulative creativity. Such a doctrine has the additional virtue of avoiding distortion of the fair use doctrine. See Leval, 103 HARV. L. REV. at 1131, n. 114 (confessing with the benefit of hindsight that his "belief that the [Salinger biography] should not be enjoined made [him] too disposed to find fair use where some of the quotations had little fair use justification”); Peter S. Menell \& Ben Depoorter, Using Fee Shifting to Promote Fair Use and Fair Licensing, 102 CAL. L. REV. 53, 80-81 (2014) (suggesting that a similar motivation might have been in play in Bill Graham Archives v. Dorling Kindersley Ltd., 448 F.3d 605 (2d Cir. 2006)).

Those general considerations should inform the crafting of copyright doctrine. Nonetheless, there is little basis in this case to deny an injunction against continued dissemination of BoLDLY. The harm to DSE appears serious and the blatant unjustified infringement favors DSE. Furthermore, the publication of a mashup- 
inspired sequel does not rise to same public importance as the dissemination of vital historical information. See Jon O. Newman, Not the End of History: The Second Circuit Struggles with Fair Use, 37 J. COPYRIGHT SOC’y U.S.A. 12, 16 (1990).

Finally, Congress could reform the Copyright Act to ease the path for mashups. Advances in digital technologies have unleashed a digital tsunami that continues to reshape the content industries and the broader culture. While these technologies have empowered creators and enabled them to reach vast audiences, they have also introduced new challenges deserving of legislative attention. Cf. Peter S. Menell, Adapting Copyright for the Mashup Generation, 164 U. PA. L. REV. 441 (2016) (advocating a compulsory license for music mashups). The present case highlights the bargaining leverage and transaction cost challenges facing upstart creators seeking to build on existing works. There are numerous ways in which Congress could lubricate the wheels of progress. See, e.g., Menell \& Depoorter, supra, (proposing a novel mechanism that would afford a limited, cost-effective process for preclearing works, promote fair negotiation over cumulative uses of copyrighted works, and reduce the exposure of cumulative creators to the inherent risks of relying on copyright's de minimis and/or fair use doctrines.) 


\section{CONCLUSIONS}

The District Court's determination that a slavish, non-parodic, conventional mashup of a highly original illustrated book is "highly transformative” and constitutes fair use fundamentally misapplies the standards for fair use analysis, undermines the statutory right to prepare derivative works, and destabilizes essential copyright law principles that have long supported markets for collaborations and derivative works. The court should reverse the District Court's grant of summary judgment for the defendants and order entry of judgment for the plaintiff.

Dated: August 12, 2019

Respectfully submitted,

Is/ Peter S. Menell

PETER S. MENELL

Counsel of Record

Koret Professor of Law and Director

Berkeley Center for Law \& Technology

UC BERKELEY SCHOOL OF LAW

225 Bancroft Way

Berkeley, CA 94720

pmenell@law.berkeley.edu

(510) 642-5489 


\section{CERTIFICATE OF SERVICE}

I certify that I electronically filed this BRIEF AMICI CURIAE OF PROFESSORS

PETER S. MENELL, SHYAMKRISHNA BALGANESH, AND DAVID

NIMMER IN SUPPORT OF PETITIONERS with the United States Court of

Appeals for the Ninth Circuit via the Court's CM/ECF system on August 12, 2019, and that service will be made on counsel of record for all parties to this case through the Court's CM/ECF system.

/s/ Peter S. Menell

PETER S. MENELL

Counsel of Record

Koret Professor of Law and Director

Berkeley Center for Law \& Technology

UC BERKELEY SCHOOL OF LAW

225 Bancroft Way

Berkeley, CA 94720

pmenell@law.berkeley.edu

(510) 642-5489 


\section{UNITED STATES COURT OF APPEALS \\ FOR THE NINTH CIRCUIT}

\section{Form 8. Certificate of Compliance for Briefs}

\section{9th Cir. Case Number(s) 19-55348}

I am the attorney or self-represented party.

This brief contains 5901 words, excluding the items exempted by Fed. R. App. P. 32(f). The brief's type size and typeface comply with Fed. R. App. P. 32(a)(5) and (6).

I certify that this brief (select only one):

[ ] complies with the word limit of Cir. R. 32-1.

[ ] is a cross-appeal brief and complies with the word limit of Cir. R. 28.1-1.

[x] is an amicus brief and complies with the word limit of Fed. R. App. P. 29(a)(5), Cir. R. 29-2(c)(2), or Cir. R. 29-2(c)(3).

[ ] is for a death penalty case and complies with the word limit of Cir. R. 32-4.

[ ] complies with the longer length limit permitted by Cir. R. 32-2(b) because (select only one):

[ ] it is a joint brief submitted by separately represented parties;

[ ] a party or parties are filing a single brief in response to multiple briefs; or

[ ] a party or parties are filing a single brief in response to a longer joint brief.

[ ] complies with the length limit designated by court order dated

[ ] is accompanied by a motion to file a longer brief pursuant to Cir. R. 32-2(a).

Signature s/Peter S. Menell

Date August 12, 2019 